\title{
GAMBARAN ASAM URAT PADA LANSIA DI WILAYAH KAMPUNG SELAYAR KOTA MAKASSAR
}

\author{
Muhammad Nasir \\ Jurusan Analis Kesehatan Poltekkes Kemenkes Makassar
}

Koresponden: nasir@poltekkes-mks.ac

\begin{abstract}
ABSTRAK
Penelitian ini dilatarbelakangi karena pada umumnya yang sering terserang asam urat adalah seseorang yang sudah lanjut usia karena telah terjadi penurunan fungsi dari berbagai organ-organ tubuhnya.Tujuan penelitian ini untuk mengetahui gambaran asam urat pada lansia laki-laki dan lansia perempuan yang memiliki hormon berbeda. Jenis penelitian ini adalah eksperimen semu yang bersifat deskriptif yang menggambarkan kadar asam urat pada lansia. Sampel dalam penelitian sebanyak 20 sampel, 10 sampel lansia laki-laki dan 10 sampel lansia perempuan. Hasil penelitian menunjukkan nilai rata-rata kadar asam urat pada lansia laki-laki lebih tinggi yaitu $(7,73 \mathrm{mg} / \mathrm{dl})$ dibandingkan nilai rata-rata kadar asam urat pada lansia perempuan yaitu ( 7,24 mg/dl). Dari hasil penelitian, dapat disimpulkan bahwa lansia laki-laki memiliki kadar asam urat lebih tinggi dibandingkan lansia perempuan. Berdasarkan kesimpulan di atas maka disarankan untuk mengatur pola makan, mengurangi makanan tinggi purin, mengonsumsi banyak karbohidrat, mengonsumsi buah-buahan yang mengandung banyak air. Serta institusi terkait agar melakukan penyuluhan tentang asam urat. Dan bagi peneliti selanjutnya, perlu dilakukan penelitian mengenai hubungan asam urat dengan penyakit lainnya seperti diabetes mellitus, jantung, gangguan ginjal, dan oesteoporosis.
\end{abstract}

Kata kunci: Asam Urat, Lansia

\section{PENDAHULUAN}

Asam urat sudah dikenal sejak 2.000 tahun yang lalu dan menjadi penyakit tertua yang dikenal manusia. Dulu, penyakit ini juga disebut "penyakit para raja" karena penyakit ini diasosiasikan dengan kebiasaan mengkonsumsi makanan dan minuman yang enak-enak. Kini, asam urat bisa menimpa siapa saja yaitu para penggemar makanan enak.

Asam urat merupakn hasil metabolisme di dalam tubuh, yang kadarnya tidak boleh berlebihan. Penyakit asam urat atau arthritias gout merupakan jenis penyakit rematik yang paling ditakuti. Pasalnya, rematik yang menyerang persendian ini tidak hanya terjadi pada usia lanjut tetapi juga terjadi pada usia produktif (30-50 tahun). Penyebab utamanya adalah tingginya kadar asam urat dalam darah yang bisa dipicuh oleh bermacam faktor. Rasa nyeri hebat pada persendian yang dirasakan berulang-ulang sangat mengganggu penderitanya. Jika tidak segera diatasi, penyakit ini juga bisa menyebabkan kelainan bentuk tulang serta komplikasi gangguan ginjal, 
jantung, diabetes mellitus, stork, dan oesteoporosis. (Safitri A, 2012).

Jika kadar asam urat dalam darah seseorang melebihi ambang normal maka asam urat ini akan masuk ke dalam tubuh khususnya ke dalam sendi. Sendi-sendi yang diserang pada umumnya, adalah sendi-sendi jempol jari kaki, pangkal jari-jari kaki, pergelangan kaki, tetapi kadangkadang juga menyerang sendi lutut, tangan, siku, bahu, dan lain-lain. Penyebab kadar asam urat di dalam darah menjadi tinggi bisa primer (ada faktor bawaan), bisa sekunder (faktor dari luar, misalnya diet yang salah atau penyakit tertentu), bisa juga campuran antara primer dan sekunder. (Kertia N, 2009).

Kadar rata-rata asam urat di dalam darah dan serum tergantung usia dan jenis kelamin. Asam urat tergolong normal apabila pada pria dibawah $7 \mathrm{mg} / \mathrm{dl}$ dan wanita dibawah $6 \mathrm{mg} / \mathrm{dl}$. (Misnadiarly, 2007).

Perbandingan pria dan wanita dalam angka kejadian gout adalah sekitar 7:1 sampai 9:1. Pria lebih banyak terkena gout, terutama yang sedang memasuki usia dewasa muda karena hormon androgen pada pria usia dewasa lebih aktif. Sedangkan pada wanita, memiliki hormon estrogen yang mampu menurunkan resiko penumpukan asam urat. Namun ketika lanjut usia hormon estrogen pada wanita sudah tidak aktif sehingga resiko arthritias gout semakin meningkat. (Soeroso J, dkk. 2012).

Umumnya yang sering terserang asam urat adalah seseorang yang sudah lanjut usia. Seseorang dikatakan lanjut usia jika usianya lebih dari 60 tahun. Penyebab penyakit pada lansia berasal dari dalam tubuh (endogen), sedangkan pada orang dewasa berasal dari luar tubuh (eksogen). Hal ini disebabkan karena pada lansia telah terjadi penurunan fungsi dari berbagai organ-organ tubuh akibat kerusakan sel-sel karena proses menua. Sehingga produksi hormon, enzim dan zat-zat yang diperlukan untuk kekebalan tubuh menjadi berkurang. Dengan demikian, lansia akan lebih mudah terkena infeksi. (Maryam dkk, 2008).

Mengingat asam urat sangat mudah menyerang para lansia maka penelitian ini di anggap cukup penting untuk mengetahui "gambaran asam urat pada lansia". Tujuan penelitian ini adalah untuk mengetahui gambaran hasil pemeriksaan kadar asam urat pada lansia di Kampung Selayar Kota Makassar.

\section{METODE}

Jenis, Lokasi dan Waktu Penelitian Jenis penelitian ini dilakukan secara eksperimen semu, yaitu melakukan pengujian secara laboratorium yang bersifat deskriptif dengan teknik analisis kuantitatif. Lokasi penelitian ini telah dilakukan di kampus Analis Kesehatan Poltekkes Makassar. Penelitian ini dilaksanakan pada bulan juni 2013.

$\begin{aligned} & \text { Populasi, } \\ & \text { Pengambilan } \\ & \text { bahan }\end{aligned}$
Sampel, alat dan

Populasi dalam penelitian ini adalah semua lansia yang ada di wilayah Kampung Selayar kota Makassar. Sampel pada penelitian ini adalah Lansia di atas 60 tahun sesuai kriteria yang ada di Kampung Selayar kota Makassar. Dalam penelitian ini sampel yang akan diteliti yaitu 10 
sampel lansia laki-laki dan 10 sampel lansia perempuan. Teknik pengambilan sampel secara purposive sampling. Alat yang digunakan adalah Mikropipet $1000 \mu$ | dan $20 \mu$, tabung reaksi, rak tabung, Fotometer, Spoit 3cc, Cenrifuge, turniquet/pembendung, tips kuning dan tips biru. Bahan yang digunakan adalah serum, reagen uric acid, kapas alcohol $70 \%$.

Reaksi :

$$
\begin{aligned}
& \text { Uric acid }+\mathrm{O}_{2}+2 \mathrm{H}_{2} \mathrm{O} \stackrel{\text { uricase }}{\longrightarrow} \text { allantoin }+\mathrm{CO}_{2}+\mathrm{H}_{2} \mathrm{O} \\
& 2 \mathrm{H}_{2} \mathrm{O}+\mathrm{DCHBS}+\mathrm{PAP} \stackrel{\text { peroxidase }}{\longrightarrow} \mathrm{N} \text {-(4-antiphyryl-3-chloro-5-Sulfonate-p- } \\
& \text { benzoquinoni mine }+\mathrm{HCl}+4 \mathrm{H}_{2} \mathrm{O}
\end{aligned}
$$

Komposisi reagen terdiri dari: Phosphate buffer $(\mathrm{Ph} 7,0) \quad 50$ $\mathrm{mmol} / \mathrm{l}, 4$-aminophenazone $\quad 0,3$ $\mathrm{mmol} / \mathrm{l}$, DCHBS $4 \mathrm{mmol} / \mathrm{l}$, Uricase> 200 U/l, Peroxidase> 1000 U/l, Reagen standar uric acid $8 \mathrm{mg} / \mathrm{dl}$.

Tahapan Pra Analitik

Persiapan sampel:

Disiapkan alat dan bahan yang akan digunakan.Dilakukan pembendungan lengan, kemudian di disinfektan dengan mengunakan kapas alkohol $70 \%$. Ditekan kulit atas vena dengan jari-jari agar vena tidak bergerak, kemudian di tusuk dengan jarum sampai jarum masuk ke dalam lumen vena dengan posisi lubang dan skala spoit menghadap ke atas. Bila sudah masuk ke dalam vena tarik bagian belakang spoit kemudian diisap pelan-pelan agar darah keluar. Darah dimasukan ke dalam tabung reaksi, kemudian centrifuge.

Tahapan Analitik

Pemeriksaan asam urat metode Enzymatic Colorimetric Siapkan 3 tabung reaksi (blanko, standar, sampel). Pipet ke dalam tabung
Metode Enzymatic Colorimetri: $\mathrm{H}_{2} \mathrm{O}_{2}$ dengan katalisa Peroxidase bereaksi dengan 3,5-dichloro-2-hydroxy benzene sulofonic acid (DCHBS) dan 4-aminophenazone

(PAP) memberikan warna merah-violet dengan Quinoneimine sebagi indikator. Intensitas warna yang terbentuk diukur secara fotomet

\section{Prosedur Kerja}

standar, reagen standar sebanyak 20 $\mu 1$. Pipet ke dalam tabung sampel, serum sebanyak $20 \mu$ l. Pipet ke dalam tabung blanko, standar, dan sampel reagen kerja masing-masing sebanyak $1000 \mu \mathrm{l}$. Homogenkan, inkubasi selama 10 menit pada suhu 20-25 ${ }^{\circ} \mathrm{C}$ dan selama 5 menit pada suhu $37^{0}$ C. Baca pada Fotometer humalyzer 2000 dengan panjang gelombang $546 \mathrm{~nm}$.

Tahap pasca Analitik

Pencatatan dan pelaporan hasil.

Nilai normal

Laki-laki : 3,4-7,0 mg/dl

Perempuan: $2,5-5,7 \mathrm{mg} / \mathrm{dl}$

\section{Analisa data}

Hasil penelitian ini disajikan dalam bentuk tabulasi dan dianalisis secara deskriptif.

\section{HASIL}

Berdasarkan hasil tentang gambaran asam urat pada lansia yang telah dilakukan dengan jumlah sampel sebanyak 20 yaitu 10 sampel lansia perempuan dan 10 sampel lansia lakilaki, maka diperoleh hasil sebagai berikut. 
Tabel 1.

Hasil pemeriksaan asam urat metode Enzymatic Colorimetric dengan menggunakan alat Photometer humalyzer 2016.

\begin{tabular}{lllllc} 
No & $\begin{array}{l}\text { Kode } \\
\text { sampel }\end{array}$ & $\begin{array}{l}\text { Jenis } \\
\text { Kelamin }\end{array}$ & $\begin{array}{l}\text { kadar } \\
\text { asam urat }\end{array}$ & Satuan & $\begin{array}{c}\text { Nilai } \\
\text { normal }\end{array}$ \\
\hline 1 & $\mathrm{~A}$ & $\mathrm{P}$ & 6,2 & $\mathrm{mg} / \mathrm{dl}$ & $2,5-5,7$ \\
2 & $\mathrm{~B}$ & $\mathrm{P}$ & 9,3 & $\mathrm{mg} / \mathrm{dl}$ & $2,5-5,7$ \\
3 & $\mathrm{C}$ & $\mathrm{P}$ & 7,2 & $\mathrm{mg} / \mathrm{dl}$ & $2,5-5,7$ \\
4 & $\mathrm{D}$ & $\mathrm{P}$ & 8,8 & $\mathrm{mg} / \mathrm{dl}$ & $2,5-5,7$ \\
5 & $\mathrm{E}$ & $\mathrm{P}$ & 7,1 & $\mathrm{mg} / \mathrm{dl}$ & $2,5-5,7$ \\
6 & $\mathrm{~F}$ & $\mathrm{P}$ & 7,5 & $\mathrm{mg} / \mathrm{dl}$ & $2,5-5,7$ \\
7 & $\mathrm{G}$ & $\mathrm{P}$ & 6,6 & $\mathrm{mg} / \mathrm{dl}$ & $2,5-5,7$ \\
8 & $\mathrm{H}$ & $\mathrm{P}$ & 6,5 & $\mathrm{mg} / \mathrm{dl}$ & $2,5-5,7$ \\
9 & $\mathrm{I}$ & $\mathrm{P}$ & 6,1 & $\mathrm{mg} / \mathrm{dl}$ & $2,5-5,7$ \\
10 & $\mathrm{~J}$ & $\mathrm{P}$ & 7,1 & $\mathrm{mg} / \mathrm{dl}$ & $2,5-5,7$ \\
11 & $\mathrm{~K}$ & $\mathrm{~L}$ & 9,6 & $\mathrm{mg} / \mathrm{dl}$ & $3,4-7,0$ \\
12 & $\mathrm{~L}$ & $\mathrm{~L}$ & 7,7 & $\mathrm{mg} / \mathrm{dl}$ & $3,4-7,0$ \\
13 & $\mathrm{M}$ & $\mathrm{L}$ & 7,2 & $\mathrm{mg} / \mathrm{dl}$ & $3,4-7,0$ \\
14 & $\mathrm{~N}$ & $\mathrm{~L}$ & 6,9 & $\mathrm{mg} / \mathrm{dl}$ & $3,4-7,0$ \\
15 & $\mathrm{O}$ & $\mathrm{L}$ & 7,3 & $\mathrm{mg} / \mathrm{dl}$ & $3,4-7,0$ \\
16 & $\mathrm{P}$ & $\mathrm{L}$ & 7,5 & $\mathrm{mg} / \mathrm{dl}$ & $3,4-7,0$ \\
17 & $\mathrm{Q}$ & $\mathrm{L}$ & 9,1 & $\mathrm{mg} / \mathrm{dl}$ & $3,4-7,0$ \\
18 & $\mathrm{R}$ & $\mathrm{L}$ & 8,1 & $\mathrm{mg} / \mathrm{dl}$ & $3,4-7,0$ \\
19 & $\mathrm{~S}$ & $\mathrm{~L}$ & 7,1 & $\mathrm{mg} / \mathrm{dl}$ & $3,4-7,0$ \\
20 & $\mathrm{~T}$ & $\mathrm{~L}$ & 6,8 & $\mathrm{mg} / \mathrm{dl}$ & $3,4-7,0$ \\
\hline
\end{tabular}

\section{PEMBAHASAN}

Penelitian ini bersifat deskriptif yang menggambarkan kadar asam urat pada lansia laki-laki dan lansia perempuan yang ada di wilayah kampung selayar kota Makassar

Dari tabel 1. di atas diperoleh hasil kadar rata-rata asam urat pada lansia perempuan yaitu $7,24 \mathrm{mg} / \mathrm{dl}$ sedangkan pada lansia laki-laki diperoleh kadar rata-rata asam urat $7,73 \mathrm{mg} / \mathrm{dl}$. Hal ini menunjukkan bahwa lansia sangat beresiko terkena asam urat. Asam urat tergolong normal apabila pada laki-laki antar $3,4-7,0 \mathrm{mg} / \mathrm{dl}$ dan perempuan antara 2,5-5,7 mg/dl.

Pada laki-laki lebih banyak terkena asam urat, terutama yang sedang memasuki usia dewasa muda karena hormon androgen pada pria usia dewasa lebih aktif. Sedangkan pada wanita, memiliki hormon strogen yang mampu menurunkan 
resiko penumpukan asam urat. Namun ketika lanjut usia hormon estrogen pada wanita sudah tidak aktif sehingga resiko asam urat semakin meningkat. (Soeroso J, dkk. 2012).

Penyakit asam urat biasanya ditandai dengan rasa nyeri hebat yang tiba-tiba menyerang sendi dan disertai dengan gejala pembengkakan, kemerahan,terasa panas, dan nyeri yang luar biasa pada saat malam hari atau di saat bangun tidur pada pagi harinya.

Pemeriksaan laboratorium terhadap kadar asam urat dapat dilakukan dengan metode Tes Strip dan metode Enzymatic Colorimetric. Kedua metode ini memiliki kelebihan dan kelemahan. Kesalahan hasil pemeriksaan asam urat sangat dipengaruhi oleh beberapa faktor mulai dari tahap pra analitik, suhu dan waktu inkubasi, reagen yang rusak, tips dan tabung reaksi yang digunakan berulang-ulang, dan alat fotometer yang tidak baik.

\section{KESIMPULAN}

Berdasarkan hasil penelitian yang dilakukan dapat ditarik kesimpulan bahwa hasil pemeriksaan kadar asam urat dengan menggunakan metode Enzymatic Colorimetric mulai meningkat pada usia lanjut.

\section{SARAN}

1. Bagi masyarakat yang sudah lansia agar dapat mengatur pola makannya dengan cara menghindari makanan-makanan yang tinggi purin, mengurangi mengonsumsi lemak, mengonsumsi banyak karbohidrat, dan mengonsumsi buah-buahan yang banyak mengandung air.

2. bagi institusi terkait agar melakukan penyuluhan tentang asam urat.

3. Untuk peneliti selanjutnya, perlu dilakukan penelitian mengenai hubungan asam urat dengan penyakit lainnya seperti diabetes mellitus, jantung, gangguan ginjal, dan oesteoporosis.

\section{DAFTAR PUSTAKA}

Kertia Nyoman , 2009. Asam Urat. Penerbit B First PT Benteng Pustaka, Yoygayakarta

Misnadiarly, 2007. Asam Urat, Hiperurisemia, Arthtritis Gout. Penerbit Pustaka Obor Populer, Jakarta.

Safitri A, 2012. Deteksi Dini Gejala, Pencegahan dan Pengobatan Asam Urat. Penerbit Pinang Merah, Yogyakarta.

Soeroso J, dkk. 2012. Asam Urat. Penerbit Penebar Swadaya Grup. Jakarta.

Sitti Maryam R, 2008. Mengenal Usia Lanjut dan Perawatannya. Penerbit Salemba Mediaka, Jakarta. 